\title{
Effects of 17-allylamino-17-demethoxygeldanamycin on the induction of apoptosis and cell cycle arrest in HCT-116 cells
}

\author{
XUERONG ZHAO $^{1}$, JIANPING WANG $^{1}$, LIJUN XIAO ${ }^{1}$, QIAN XU $^{2}$, ENHONG ZHAO $^{3}$, \\ $\mathrm{XIN}_{\mathrm{ZHENG}}{ }^{3}$, HUACHUAN ZHENG ${ }^{4}$, SHUANG ZHAO ${ }^{4}$ and $\mathrm{SHI} \mathrm{DING}^{5}$
}

\begin{abstract}
Departments of ${ }^{1}$ Immunology and ${ }^{2}$ Fundamental Research, Chengde Medical University, Chengde, Hebei 067000; ${ }^{3}$ The Third Department of Surgery, The Affiliated Hospital of Chengde Medical University, Chengde, Hebei 067000;

${ }^{4}$ Cancer Research Center, The First Affiliated Hospital of Liaoning Medical University, Jinzhou, Liaoning 121000;

${ }^{5}$ Pharmocology Department, Chengde Medical University, Chengde, Hebei 067000, P.R. China
\end{abstract}

Received July 24, 2015; Accepted January 6, 2017

DOI: $10.3892 / 01.2017 .6442$

\begin{abstract}
The present study investigated the effects of HSP90 inhibitor 17-allylamino-17-demethoxygeldanamycin (17-AAG) on apoptosis and the cell cycle of the HCT-116 human colon carcinoma cell line, with the aim of elucidating their underlying mechanisms. MTT was used to examine the inhibitory effects of 17-AAG on the proliferation of HCT-116 cells at various time points and doses. The cells were stained with Annexin V-fluorescein isothiocyanate/propidium iodide and evaluated by flow cytometry. The expression of signal transducer and activator of transcription (STAT)3, cyclin D1, cytochrome $c$ (cyt- $c$ ), caspase 9 and caspase 3 at the mRNA and protein level was determined using reverse transcription-polymerase chain reaction and western blotting. Treatment with 17-AAG at a concentration of $1.25-20 \mathrm{mg} / 1$ for 24 and $48 \mathrm{~h}$ significantly inhibited the proliferation of HCT-116 cells in a time-dependent and concentration-dependent manner. Treatment with 17-AAG at concentrations of $1.25,2.5$ and $5 \mathrm{mg} / \mathrm{l}$ for $48 \mathrm{~h}$ significantly induced apoptosis and cell cycle arrest in HCT-116 cells. Exposure to 17-AAG at concentrations of $1.25,2.5$ and $5 \mathrm{mg} / \mathrm{l}$ for $48 \mathrm{~h}$ significantly downregulated the mRNA and protein expression of STAT3 and cyclin D1, but upregulated cyt- $c$, caspase 9 and caspase 3 in a concentration-dependent manner in HCT-116 cells. Therefore 17-AAG is able to inhibit cell proliferation, inducing apoptosis and $\mathrm{G}_{1}$ stage cell cycle arrest by downregulating the expression of cyclin D1, and promoting the mitochondria apoptosis by downregulating STAT3 in HCT-116 cells.
\end{abstract}

Correspondence to: Professor Lijun Xiao, Department of Immunology, Chengde Medical University, Anyuan Street, Chengde, Hebei 067000, P.R. China

E-mail: xiaolijun1233@163.com

Key words: 17-allylamino-17-demethoxygeldanamycin, HCT-116 cells, apoptosis, cell cycle, signal transducer and activator of transcription 3

\section{Introduction}

Colon cancer is the third most prevalent type of human cancer, which is cured primarily via surgical excision and chemotherapy (1). Therapeutic methods utilizing molecular targets to alter cancer cell properties possess more powerful antitumor functions and fewer toxic effects towards healthy cells (2). As a result, small molecule target therapeutics for cancer has been the subject of numerous investigations (2). The heat shock protein (hsp) family, particularly hsp90, is associated with the stability of a number of key oncogenic target proteins, including receptor and non-receptor tyrosine kinases, and is therefore a promising molecular target for cancer treatment (3). Increased levels of hsp90 expression affects the early-stage of carcinogenesis and the morphology of cancer cells, which is associated with the therapeutic effects of hsp90 inhibitors (4). As a potent anti-cancer treatment, a number of hsp90 inhibitors have been the subjects of several studies $(5,6)$. The overexpression of hsp90 has been demonstrated in colon cancer and is associated with the proliferation of colon cancer cells.

17-allylamino-17-demethoxygeldanamycin (17-AAG) is a derivative of geldanamycin (an hsp90 inhibitor), which specifically interacts with the N-terminal ATP binding domain of hsp90, inhibiting the intrinsic ATPase activity that is important for its chaperone function (7). Subsequently, hsp90 substrate proteins are degraded via the ubiquitin-proteasome pathway. The majority of these substrate proteins are signaling molecules involved in numerous signaling pathways that influence tumor development (8). The present study aimed to elucidate the effects of 17-AAG on the cell cycle, proliferation and apoptosis of HCT-116 cells, and investigate the molecular mechanisms underlying the effect of 17-AAG treatment on colon cancer cells.

\section{Materials and methods}

Cell culture. The HCT-116 human colon carcinoma cell line was provided by Professor Zheng Huachuan of The First Affiliated Hospital of Liaoning Medical University (Jinzhou, China). The cells were cultured in RPMI-1640 supplemented 
with $10 \%$ fetal bovine serum (FBS) and $100 \mathrm{U} / \mathrm{ml}$ penicillin (all from Hyclone; GE Healthcare Life Sciences, Shanghai, China) and incubated at $37^{\circ} \mathrm{C}$ with $5 \% \mathrm{CO}_{2}$. Cells were monitored daily and the medium was replaced every 2-3 days as required. Cells in the logarithmic growth phase were selected and transferred to 96 -well plates $\left(5 \times 10^{4}\right.$ cells $\left./ \mathrm{ml}\right)$. Upon cell adherence, five concentrations of 17-AAG $(1.25,2.5,1.5,1.10$ and $1.20 \mathrm{mg} / \mathrm{l})$ were added to the experimental groups and an untreated control group was included. The control group was only cultured with RPMI-1640 supplemented with $10 \%$ FBS and $10 \mu 1$ RPMI-1640 was added when $10 \mu 1$ 17-AAG was added to the other groups. MTT solution was added to the wells after 24 or $48 \mathrm{~h}$, and the medium was discarded after $4 \mathrm{~h}$. Subsequently, $150 \mu 1 /$ well dimethyl sulfoxide was added and the plate was agitated for $15 \mathrm{~min}$. Optical density (OD) was evaluated at a wavelength of $490 \mathrm{~nm}$ using a microplate reader (ELX808; BioTek, China, Beijing, China). Finally, the growth inhibition rates at various doses of 17-AAG were calculated using the equation: Growth inhibition rate $=[(\mathrm{OD}$ control group) - (OD17 - AAG group)]/(OD control group - OD blank group).

Cell cycle and apoptosis assays. HCT-116 cells $\left(5 \times 10^{4} \mathrm{cells} / \mathrm{ml}\right)$ in the logarithmic phase of growth were added to petri dishes to establish a control group (RPMI-1640, 10\% FBS) and experimental groups with various concentrations $(1.25,2.5$ and $5 \mathrm{mg} / \mathrm{l})$ of 17-AAG. Following $48 \mathrm{~h}$ the cells were collected by centrifugation at $1,000 \mathrm{xg}$ at $4^{\circ} \mathrm{C}$ for $5 \mathrm{~min}$. Subsequently, $2 \mathrm{ml}$ PBS was added to each group to resuspend the cells in order to wash them. Cells for the apoptosis assay were then resuspended in $500 \mu \mathrm{l}$ binding buffer (Hangzhou Biosci Biotech Co., Ltd., Hangzhou, China) and stained with $5 \mu 1$ propidium iodide (PI) and $5 \mu 1$ Annexin V (Hangzhou Biosci Biotech Co., Ltd.) for $15 \mathrm{~min}$ at room temperature in dark. Subsequently, the cells were analyzed by Flow cytometry (BD FACSVerse; BD Biosciences, Franklin Lakes, NJ, USA). The cells for cell cycle assay were collected after $48 \mathrm{~h}$ and incubated in $70 \%$ ethanol for $12 \mathrm{~h}$ at $-20^{\circ} \mathrm{C}$. Subsequently, the cells $\left(10^{6}\right)$ were resuspended in $500 \mu \mathrm{l}$ binding buffer (Hangzhou Biosci Biotech Co., Ltd.) following centrifugation at $1,000 \mathrm{x} \mathrm{g}$ and $4^{\circ} \mathrm{C}$ for $5 \mathrm{~min}$. Ribonuclease A ( $125 \mathrm{mg} / \mathrm{ml}, 1 \mu \mathrm{l}$; Beyotime Institute of Biotechnology, Jiangsu, China) was added to the buffer and the cell suspension was incubated at $37^{\circ} \mathrm{C}$ for $30 \mathrm{~min}$. Following incubation, $5 \mu 1$ PI (Hangzhou Biosci Biotech Co., Ltd.) was added to each cell sample and incubated for $30 \mathrm{~min}$ at $20^{\circ} \mathrm{C}$ in dark. Flow cytometry (BD FACSVerse; BD Biosciences) was used to detect the cell cycle stage of HCT-116 cells and apoptotic cells.

$R N A$ extraction and reverse transcription-quantitative polymerase chain reaction (RT-PCR) analysis. HCT-116 cells at the logarithmic phase of growth were added to petri dishes to establish a control group (RPMI-1640, 10\% FBS) and experimental groups with various concentrations of 17-AAG $(1.25,2.5$ and $5 \mathrm{mg} / \mathrm{l})$. All the cells were collected after $48 \mathrm{~h}$ and added to Eppendorf tubes, following which $1 \mathrm{ml}$ TRIzol ${ }^{\circledR}$ (Thermo Fisher Scientific,Inc., Waltham, MA,USA) was added and tubes were incubated on ice for $10 \mathrm{~min}$. Subsequently, $200 \mu 1$ chloroform was added, and the cells were placed in a shaker for $15 \mathrm{sec}$ at room temperature and centrifuged for
$15 \mathrm{~min}$ at $12,000 \mathrm{x} \mathrm{g}$ and $4^{\circ} \mathrm{C}$. Following centrifugation, the upper layer of supernatant $(\sim 200 \mu \mathrm{l})$ was collected and $\sim 200 \mu \mathrm{l}$ isopropyl alcohol was added to each tube. The tubes were kept on ice for $10 \mathrm{~min}$ and centrifuged for $15 \mathrm{~min}$ at $12,000 \mathrm{x} \mathrm{g}$ and $4^{\circ} \mathrm{C}$. Subsequently, all the liquid was discarded and cells were washed with $70 \%$ ethanol diluted with diethylpyrocarbonate-treated water, and the RNA concentration of each sample was evaluated using an ultraviolet spectrophotometer.

RT-PCR was performed using the TaKaRa RNA PCR (avian myeloblastosis virus) kit (Takara Biotechnology Co., Ltd., Dalian, China) according to the manufacturer's protocol (9). Primer sequences for signal transducer and activator of transcription (STAT)3, cyclin D1, cyt-c, caspase 9 and caspase 3 are provided in Table I, and were used for DNA amplification following RT.

Western blot analysis. HCT-116 cells at the logarithmic phase of growth were added to petri dishes, including a control group (RPMI-1640, 10\% FBS) and experimental groups with various concentrations of 17-AAG (1.25 and $2.5 \mathrm{mg} / \mathrm{l})$. The cells were collected after $48 \mathrm{~h}$. Lysis buffer (M-PER ${ }^{\mathrm{TM}}$ Mammalian Protein Extraction reagent; Thermo Fisher Scientific, Inc.) was added, and the cells were incubated on ice for $20 \mathrm{~min}$. Subsequently, the cells were centrifuged for $20 \mathrm{~min}$ at $1,000 \mathrm{xg}$ and $4^{\circ} \mathrm{C}$. The upper layer of supernatant was collected, and the protein concentration was evaluated by using the Pierce ${ }^{\mathrm{TM}}$ BCA Protein Assay kit (Thermo Fisher Scientific, Inc). Total cell lysates $(30 \mu \mathrm{g})$ were separated by $12 \%$ SDS-PAGE and transferred to a polyvinylidene fluoride membrane (Merck Millipore, Darmstadt, Germany), and the blots were blocked with 5\% skimmed milk. The membranes were washed three times by using $1 \mathrm{ml}$ phosphate-buffered saline (PBS; Thermo Fisher Scientific, Inc.) for $5 \mathrm{~min}$. The blots were probed with antibodies against STAT3, cyclin D1, cyclin B1, cyt-c, caspase 9 and caspase 3 . Antibodies $(1 \mathrm{ml})$ against STAT3 against STAT3 (cat. no. ab119352), cyclin D1 (cat. no. ab134175), cyclin B1 (cat. no. ab32053), cyt- $c$ (cat. no. ab13575), caspase 9 (cat. no. ab32539) and caspase 3 (cat. no. ab32042) were added to the membranes at dilutions of 1:1,000. The membranes were placed on a shaker for $1 \mathrm{~h}$ at $20^{\circ} \mathrm{C}$. The membranes were subsequently washed three times using $1 \mathrm{ml}$ PBS for $5 \mathrm{~min}$. The secondary antibodies horseradish peroxidase (HRP)-conjugated anti-mouse immunoglobulin G (IgG; cat. no. ab131368) and HRP-conjugated anti-rabbit IgG variable domain of heavy chain single domain (cat. no. ab191866) were added to the membranes. All primary and secondary antibodies were purchased from Abcam (Shanghai, China). The membranes were placed in a shaker with the secondary antibody for $1 \mathrm{~h}$ at $20^{\circ} \mathrm{C}$, and subsequently washed 3 times with PBS. Pierce ${ }^{\mathrm{TM}}$ enhanced chemiluminescence western blotting substrate (Thermo Fisher Scientific, Inc.) was added to the membranes for $3 \mathrm{~min}$, and the membranes were captured with the ChemiDoc XRS system (Bio-Rad Laboratories, Inc., Hercules, CA, USA).

Immunofluorescence assay. HCT-116 cells at the logarithmic growth phase were added to 6-well plates on a cover glass to form a control group (RPMI-1640, 10\% FBS) and experimental groups with various concentrations of 17-AAG (1.25, 2.5 and $5 \mathrm{mg} / \mathrm{l})$. The cells were collected after $48 \mathrm{~h}$ and 
Table I. Primer sequences.

\begin{tabular}{|c|c|c|c|c|}
\hline Gene name & Sequence, $5^{\prime}-3^{\prime}$ & $\begin{array}{l}\text { Annealing } \\
\text { temperature, }{ }^{\circ} \mathrm{C}\end{array}$ & $\begin{array}{l}\text { Number } \\
\text { of cycles }\end{array}$ & $\begin{array}{l}\text { Product } \\
\text { size, bp }\end{array}$ \\
\hline STAT3 & $\begin{array}{l}\text { F: CCTCCTCAGCATCTTATCCG } \\
\text { R: CAGCCTGGGCATCCTTG }\end{array}$ & 59 & 30 & 499 \\
\hline Caspase 3 & $\begin{array}{l}\text { F: TGGACCTGTTGACCTGA } \\
\text { R: CACAAAGCGACTGGATG }\end{array}$ & 57 & 30 & 269 \\
\hline Caspase 9 & $\begin{array}{l}\text { F: TGGACCTGTTGACCTGA } \\
\text { R: CACAAAGCGACTGGATG }\end{array}$ & 57 & 30 & 885 \\
\hline Cyt- $c$ & $\begin{array}{l}\text { F: GTCCGGTTGCGCTTTCCTT } \\
\text { R: CGCAGTTTCCTCAAATTCTTTCTTC }\end{array}$ & 60 & 40 & 156 \\
\hline Cyclin D1 & $\begin{array}{l}\text { F: TGTCCTACTACCGCCTCACACGCTTCCTCTCCG } \\
\text { R: TCCTCTTCCTCCTCCTCGGCGGCCTTG }\end{array}$ & 63 & 35 & 160 \\
\hline GAPDH & $\begin{array}{l}\text { F: CAATGACCCCTTCATTGACC } \\
\text { R: TGGAAGATGGTGATGGGATT }\end{array}$ & 60 & 30 & 135 \\
\hline
\end{tabular}

GAPDH, glyceraldehyde-3-phosphate dehydrogenase; STAT3, signal transducer and activator of transcription; cyt- $c$, cytochrome $c$; bp, base pairs; F, forward; R, reverse.

washed once with PBS. Subsequently, 4\% paraformaldehyde was added to the wells, and the cells were incubated at room temperature for $15 \mathrm{~min}$ prior to 3 washes with PBS. The cells were subsequently incubated with $1 \%$ Triton X-100 for 20 min at $20^{\circ} \mathrm{C}$ and washed with PBS three times. Bovine serum albumin (1\%; Beyotime Institute of Biotechnology) was added to the wells, which were then incubated for $30 \mathrm{~min}$ at room temperature. STAT3 primary antibody (1:200) was added to the wells and incubated overnight at $4^{\circ} \mathrm{C}$. The secondary antibody goat anti-mouse $\operatorname{IgG}$ (heavy chain and light chain; 1:400; cat. no. ab96879; Abcam) was added to the wells and incubated for $2 \mathrm{~h}$ at room temperature. The cells were washed three times with PBS. Following washing, DAPI was added to the wells and incubated for $5 \mathrm{~min}$ in the dark. The cells were observed under a fluorescence microscope and images were captured.

Statistical analysis. Statistical analysis was performed with SPSS (version 19.0; IBM SPSS, Armonk, NY, USA). The data were presented as the mean \pm standard deviation. Data comparisons among groups were performed using one-way analysis of variance, and Turdey post hoc test. $\mathrm{P}<0.05$ was considered to indicate a statistically significant difference.

\section{Results}

HCT-116 cell proliferation is inhibited by 17-AAG treatment. The MTT assay results revealed that $1.25-20 \mathrm{mg} / 1$ of $17-\mathrm{AAG}$ exhibited significant inhibitory effects $(\mathrm{P}<0.01)$ on the proliferation of HCT-116 cells in a concentration-dependent manner. The cell numbers in the 17-AAG treated groups were significantly reduced $(\mathrm{P}<0.01)$, compared with those observed in the control group, with an abnormal cell morphology exhibited by the 17-AAG-treated cells (Fig. 1). The proliferation inhibition rate of 17-AAG-treated cells $(1.25,2.5,5,10$ and $20 \mathrm{mg} / \mathrm{l})$ at $48 \mathrm{~h}\left(\mathrm{IC}_{50}, 1.71 \mathrm{mg} / \mathrm{l}\right)$ was increased, compared with that observed at $24 \mathrm{~h}\left(\mathrm{IC}_{50}, 23.24 \mathrm{mg} / \mathrm{l}\right.$; Table II; Fig. 2).
17-AAG induces $G_{2}$ stage cell cycle arrest in HCT-116 cells. PI staining detection results revealed that various concentrations $(1.25,2.5$ and $5 \mathrm{mg} / \mathrm{l})$ of $17-\mathrm{AAG}$ were able to cause a significant arrest in cell cycle progression of HCT-116 cells at the $G_{2}$ stage after $48 \mathrm{~h}$. However, this effect did not appear to occur in a concentration-dependent manner (Fig. 3).

17-AAG promotes HCT-116 cell-apoptosis. The apoptotic rates of the cells in the 17-AAG-treated groups (1.25, 2.5 and $5 \mathrm{mg} / \mathrm{l})$ were markedly increased compared with cells in the control group. Additionally, 17-AAG appeared to increase the apoptosis rate of HCT-116 cells in a dose-dependent manner (Fig. 4).

17-AAG-treatment affects the $\mathrm{mRNA}$ and protein expression of STAT3, cyclin D1, cyclin B1 and caspase 3. RT-qPCR and western blot analysis results revealed that the expression levels of STAT3, cyclin D1 and cyclin B1 in the treated groups (1.25 and $2.5 \mathrm{mg} / \mathrm{l})$ were significantly reduced $(\mathrm{P}<0.01)$, compared with the control group. The expression levels of cyt- $c$, caspase 9 and caspase 3 in the 17-AAG-treated groups were significantly increased $(\mathrm{P}<0.01)$ compared with the control, in a concentration-dependent manner (Fig. 5).

17-AAG inhibits STAT3 expression. Fluorescence microscopy revealed markedly reduced STAT3 staining in the 17-AAG-treated groups (1.25, 2.5 and $5 \mathrm{mg} / \mathrm{l})$, compared with the control, in a concentration-dependent manner (Fig. 6).

\section{Discussion}

The over-expression of hsp90 has been detected in various forms of carcinoma, including breast, prostate, renal, colon, ovarian and hepatocarcinoma, multiple myeloma and leukemia (10-12). As hsp90 is a highly expressed tumor marker (13), hsp90 inhibitors may be an effective anticancer therapy. Geldanamycin, an inhibitor of the hsp90 ATP-binding 
Table II. Inhibitory effects of 17-AAG on the proliferation of HCT-116 colon carcinoma cells (mean \pm standard deviation; $\mathrm{n}=6$ ).

\begin{tabular}{|c|c|c|c|c|}
\hline \multirow[b]{2}{*}{ 17-AAG, mg/l } & \multicolumn{2}{|c|}{$24 \mathrm{~h}$} & \multicolumn{2}{|c|}{$48 \mathrm{~h}$} \\
\hline & Absorbance & Inhibitory rate, $\%$ & Absorbance & Inhibitory rate, $\%$ \\
\hline Control & $0.450 \pm 0.09$ & 0 & $0.569 \pm 0.01$ & 0 \\
\hline 1.25 & $0.399 \pm 0.01$ & $26.17^{\mathrm{a}}$ & $0.472 \pm 0.05$ & $30.14^{\mathrm{a}}$ \\
\hline 2.5 & $0.397 \pm 0.04$ & $26.61^{\mathrm{a}}$ & $0.434 \pm 0.08$ & $36.82^{\mathrm{a}}$ \\
\hline 5 & $0.392 \pm 0.004$ & $27.87^{\mathrm{a}}$ & $0.366 \pm 0.05$ & $48.65^{\mathrm{a}}$ \\
\hline 10 & $0.378 \pm 0.019$ & $30.91^{\mathrm{a}}$ & $0.302 \pm 0.04$ & $60.01^{\mathrm{a}}$ \\
\hline 20 & $0.343 \pm 0.017$ & $32.45^{\mathrm{a}}$ & $0.229 \pm 0.003$ & $72.73^{\mathrm{a}}$ \\
\hline $\mathrm{IC}_{50}$ & \multicolumn{2}{|c|}{60.08} & \multicolumn{2}{|c|}{5.24} \\
\hline
\end{tabular}

${ }^{\text {a }}<0.01$ vs. control group. $\mathrm{IC}_{50}=$ the mean value of 6 repetitions and is defined as the concentration of an inhibitor whereby the response is reduced by half. 17-AAG, 17-allylamino-17-demethoxygeldanamycin; IC, inhibitory concentration.
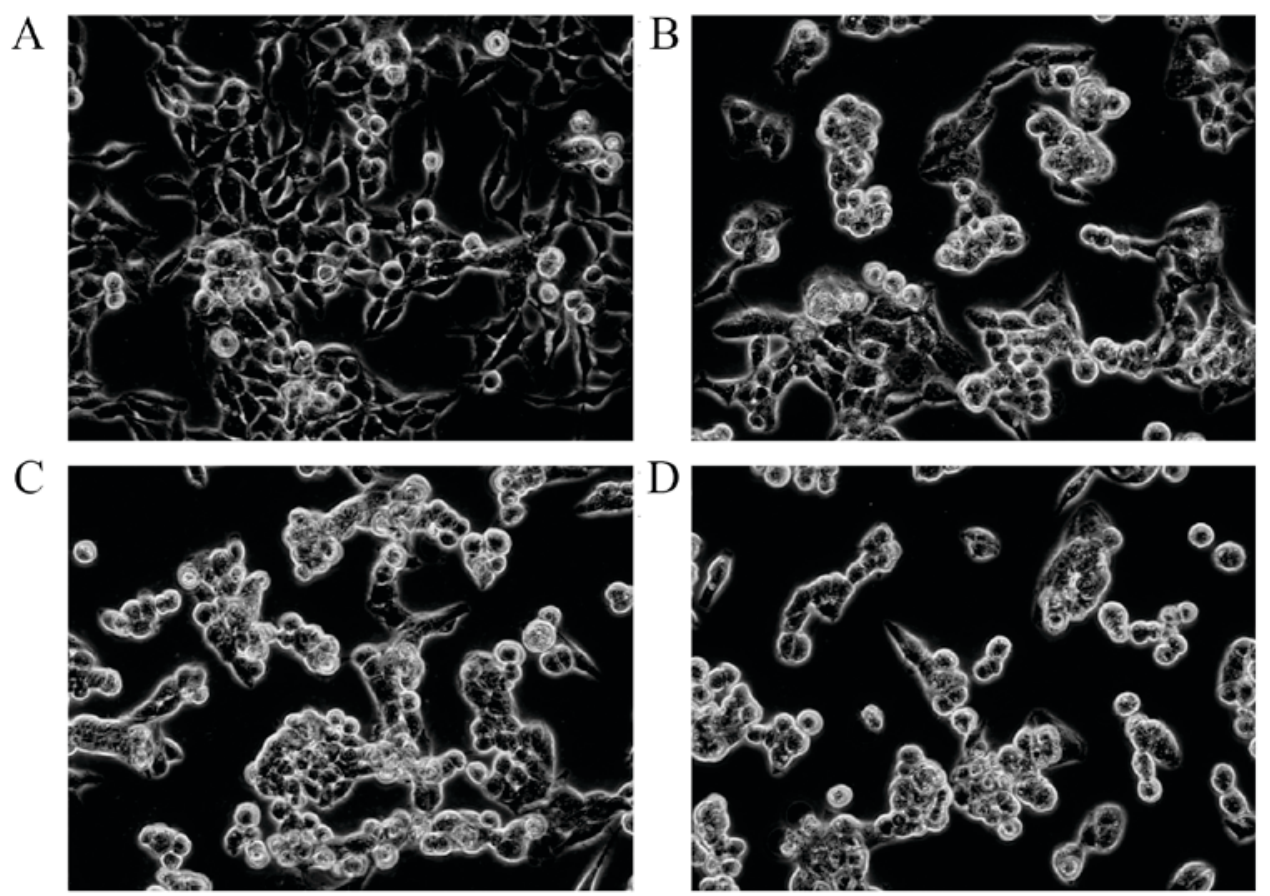

Figure 1. HCT-116 cells following culture for $48 \mathrm{~h}$ with various concentrations of 17-AAG; (A) control group; (B) $1.25 \mathrm{mg} / 1 \mathrm{group}$; (C) $2.5 \mathrm{mg} / 1 \mathrm{group}$; (D) $5 \mathrm{mg} / 1$ group. A decreased number of cells and abnormal cell morphology was observed in the 17-AAG treated groups, compared with the control. 17-AAG, 17-allylamino-17-demethoxygeldanamycin.

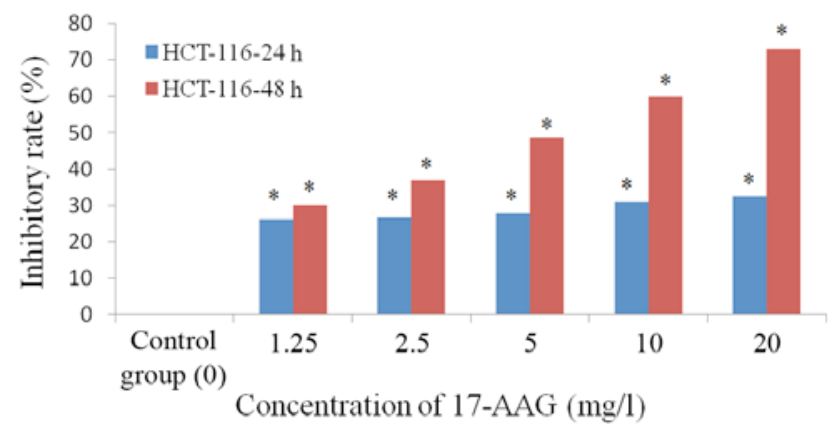

Figure 2. Inhibitory effects of 17-AAG-treatment on HCT-116 cells as assessed by flow cytometry. As the concentration of 17-AAG was increased, the inhibitory effect on the proliferation of HCT-116 cells also increased after 24 and 48 h. ${ }^{*} \mathrm{P}<0.01$ compared with the control group. 17-AAG, 17-allylamino-17-demethoxygeldanamycin. domain, was the first hsp90 inhibitor to be identified (14). This inhibitor functions by inducing the degradation of hsp90 substrates, which enables the suppression of various signaling pathways, in order to impede carcinoma angiogenesis, histogenesis and cell proliferation as well as induce cell cycle arrest and apoptosis (15). As a number of studies have revealed the high hepatotoxicity of geldanamycin, its derivative 17-AAG was investigated in the present study. 17-AAG has increased water solubility and lower hepatotoxicity $(16,17)$.

Abnormalities in cell cycle control may lead to aberrant proliferation and cancer development (17), suggesting that induction of cell cycle arrest may be a promising therapeutic approach for cancer (18). Numerous studies have reiterated the importance of the cell cycle during carcinogenesis, as well as revealing that hsp90 inhibitors are able to induce arrest 

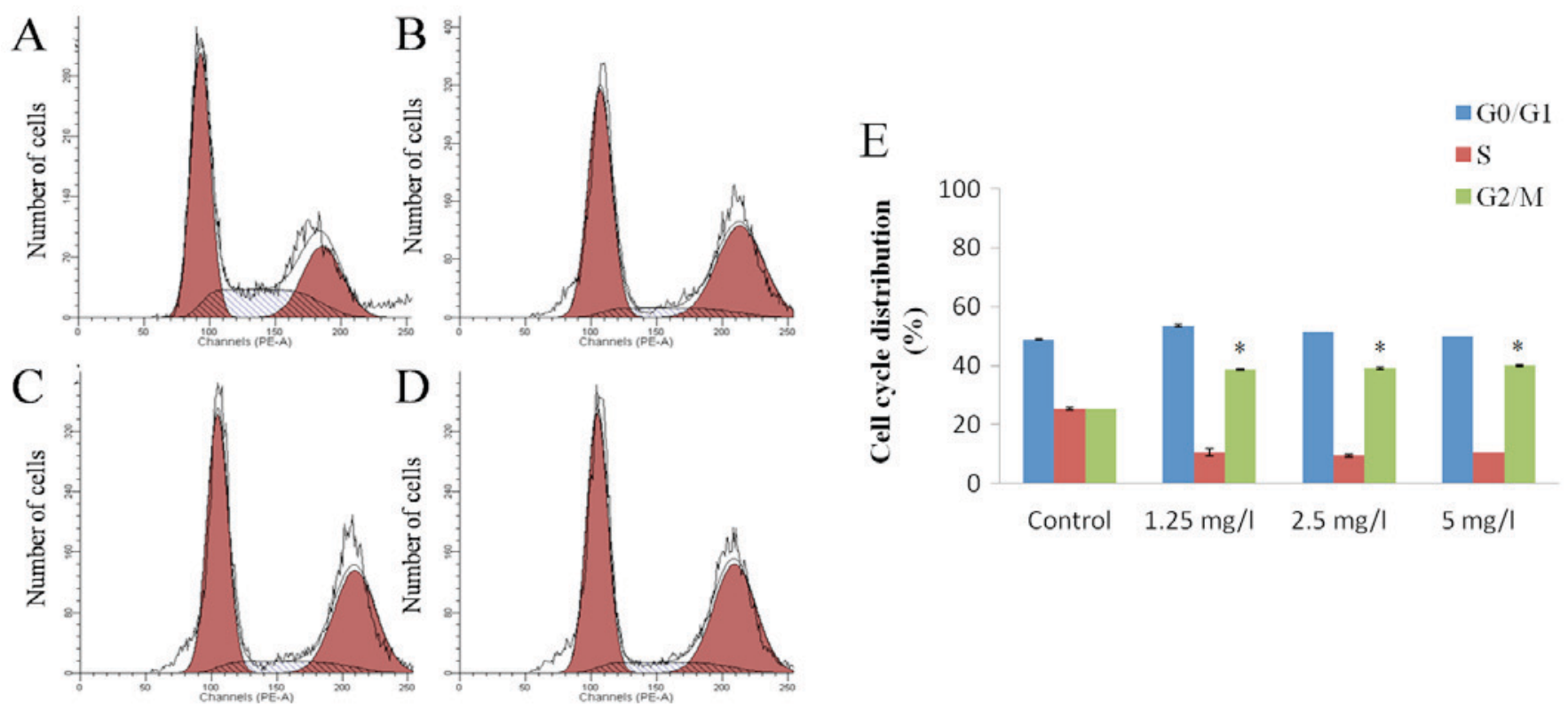

Figure 3. Effect of various concentrations of 17-AAG on the cell cycle of HCT-116 cells. (A) Control; (B) $1.25 \mathrm{mg} / 1$; (C) $2.5 \mathrm{mg} / \mathrm{l}$; (D) $5 \mathrm{mg} / 1$. (E) Bar chart showing the effect of increasing concentration of 17-AAG on cell cycle distribution. The results indicated that, in the 17-AAG treated groups, the $\mathrm{S}$ phase fraction was decreased and the $\mathrm{G}_{2} / \mathrm{M}$ phase fraction was increased, compared with the control $(\mathrm{P}<0.05)$, suggesting that 17-AAG induced cell cycle arrest of HCT-116 cells at the $\mathrm{G}_{2} / \mathrm{M}$ phase. ${ }^{*} \mathrm{P}<0.01$ compared with the control. 17-AAG, 17-allylamino-17-demethoxygeldanamycin; PE-A, phycoerythrin A.
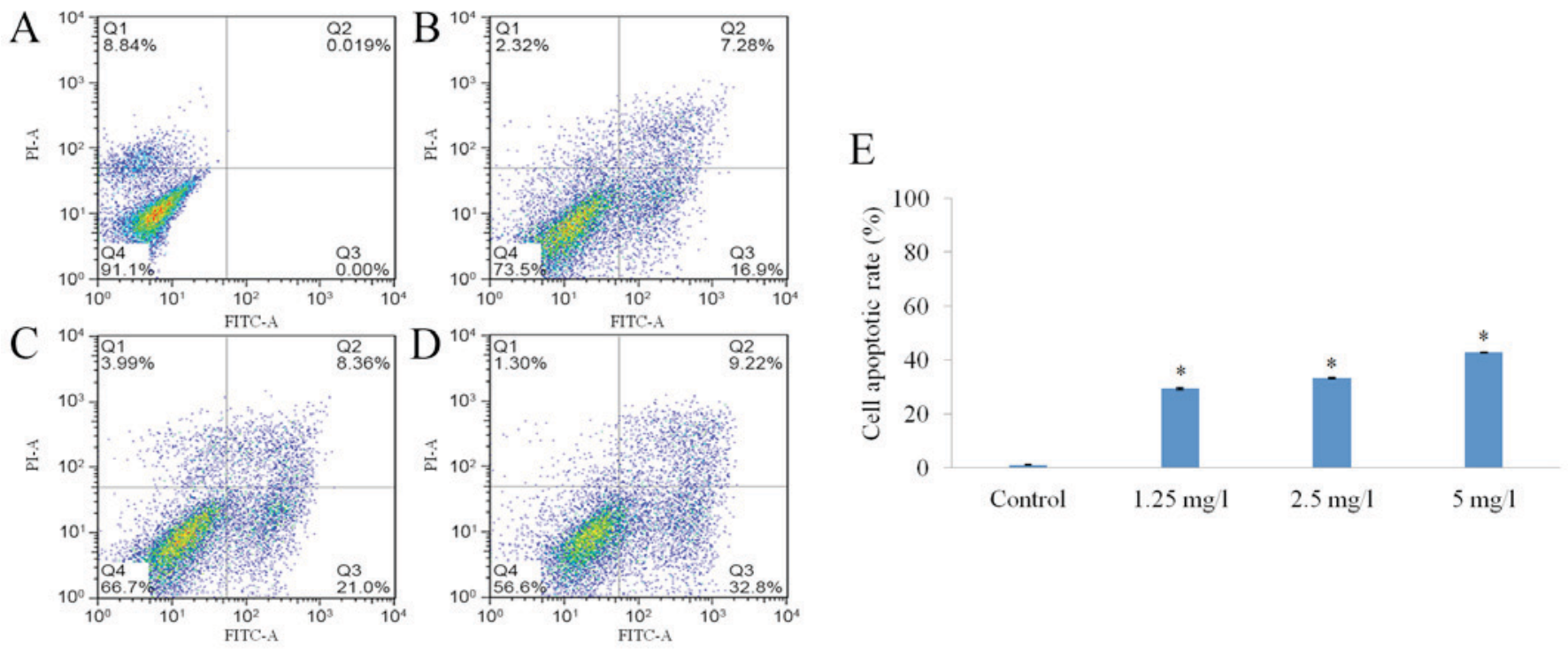

Figure 4. The effect of 17-AAG on the apoptosis of HCT-116 cells. (A) Control: $0 \mathrm{mg} / 1$; (B) $1.25 \mathrm{mg} / \mathrm{l}$; (C) $2.5 \mathrm{mg} / 1$; (D) $5 \mathrm{mg} / 1$. (E) Bar chart showing the effect of increasing concentration of 17-AAG on apoptotic rate. In comparison with the control, the apoptotic rates of the treated groups were elevated as concentration of 17-AAG increased ( $\mathrm{P}<0.05$ ). "P<0.01 compared with the control. 17-AAG, 17-allylamino-17-demethoxygeldanamycin; Q, quadrant; FITC-A, fluorescein isothiocyanate-Annexin V; PI, propidium iodide.

at different cell cycle stages in various tumor types $(19,20)$. Previous studies have suggested that treatment with 17-AAG is able to arrest SGC-7901 gastric cancer cells and HepG2 liver cancer cell lines at the $\mathrm{G}_{2} / \mathrm{M}$ stage $(21,22)$ and bladder cancer cell lines (RT4, RT112 and T24) at the $\mathrm{G}_{1}$ stage (23). In the present study 17 -AAG treatment induced $\mathrm{G}_{2}$-stage arrest in CT-116 cells in a non-concentration-dependent manner.

In order to control the cell cycle, cyclin-dependent kinases $(\mathrm{CDK})$ are primarily regulated by cyclins and $\mathrm{CDK}$ inhibitors (24). High levels of CDK expression are able to trigger anti-apoptotic mechanisms, leading to unrestricted cell proliferation (25). As one of numerous proto-oncogenes, cyclin D1 forms a complex with and activates CDK4, leading to the phosphorylation of retinoblastoma protein and the release of E2 factor (26). This process induces the initiation of $\mathrm{S}$ phase-associated gene transcription and the cell cycle transition from $\mathrm{G}_{1}$ to $\mathrm{S}$ phase (26). The present study observed mRNA-level and protein-level changes in cyclin D1, detecting reduced cyclin D1 expression in HCT-116 cells. As cells were arrested at the $\mathrm{G}_{2}$ phase, it was hypothesized that the effect of 17-AAG on the cell cycle of HCT-116 cells is not dependent on altered cyclin D1 expression levels. The cyclin B1 subunit 

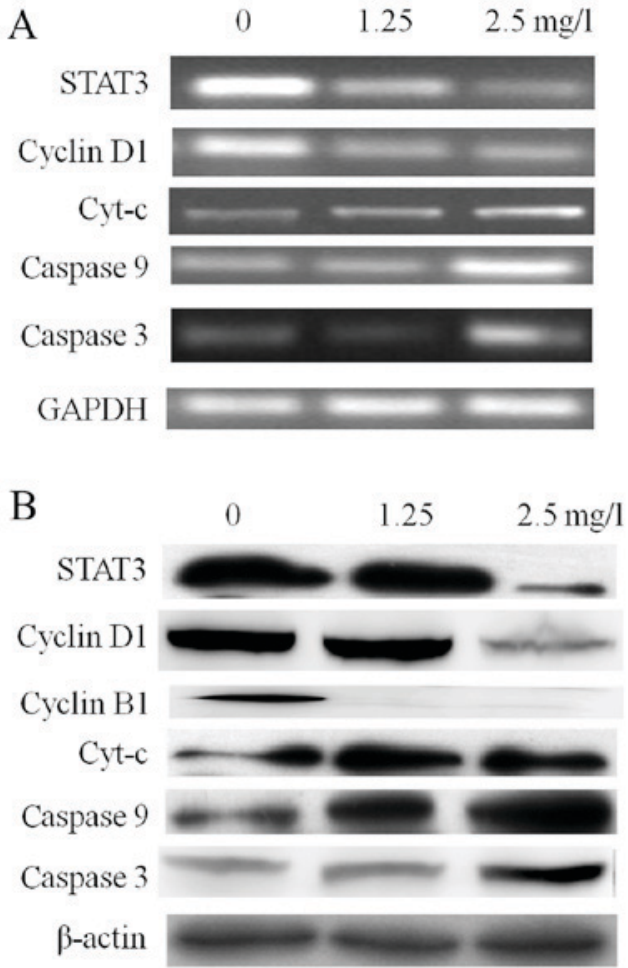
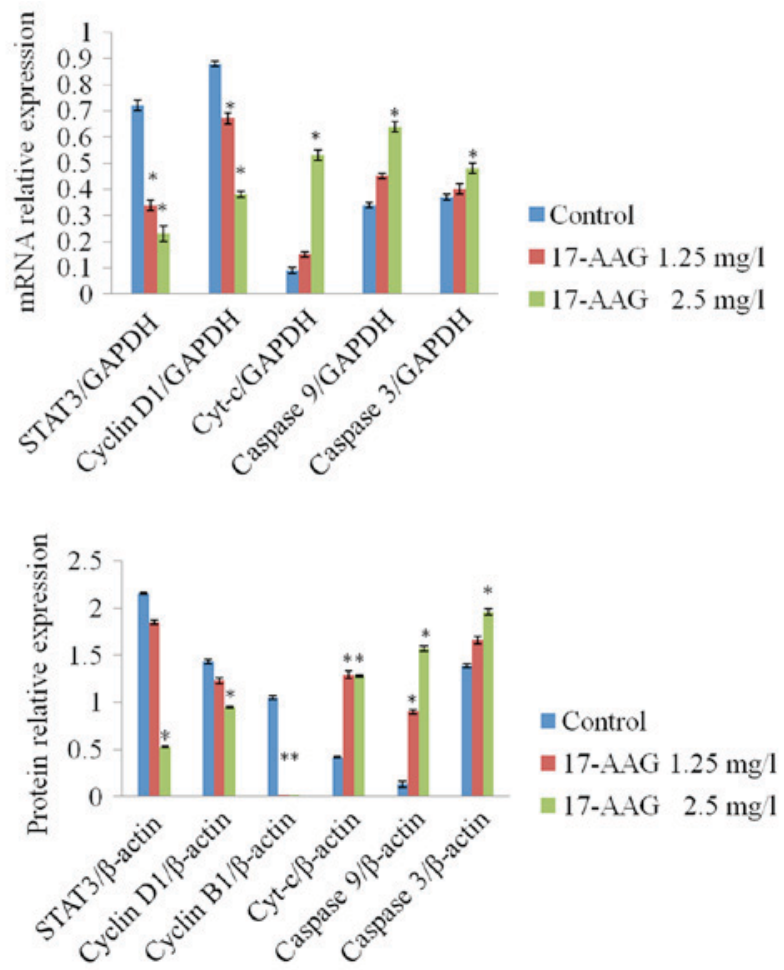

Figure 5. Effect of 17-AAG on the expression levels of various cellular factors. (A) Following treatment with 17-AAG, cyt-c, caspase 9 and caspase 3 mRNA expression levels were increased in HCT-116 cells in a concentration-dependent manner compared with the control. By contrast, STAT3 and cyclin D1 mRNA expression levels were decreased in a concentration-dependent manner, compared with the control. (B) Following 17-AAG-treatment, cyt- $c$, caspase 9 and caspase 3 protein expression was significantly increased in a concentration-dependent manner, compared with the control, whereas stat 3 , cyclin D1 and cyclin B1 expression was significantly decreased in a concentration-dependent manner, compared with the control. * $\mathrm{P}<0.05$ compared with the control. 17-AAG, 17-allylamino-17-demethoxygeldanamycin; mRNA, messenger RNA; cyt- $c$, cytochrome $c$; STAT3, signal transducer and activator of transcription 3.

binds CDK1, and this maturation-promoting factor complex promotes progression from the $\mathrm{G}_{2}$ to $\mathrm{M}$ phase of the cell cycle (27). Following activation, the cyclin B1-CDK1 complex is able to initiate the prophase of mitosis, suggesting that an increase in its activity may lead to alterations in the mitotic behavior of the cell (28). Therefore, the expression levels and activity of cyclin B1 and CDK1 are able to influence cell mitosis. During the present study, HCT-116 cells were arrested at the $G_{2}$ phase and cyclin B1 expression levels were significantly decreased. This result is contrary to a previous study, suggesting that the HCT-116 cell cycle is not influenced by 17-AAG treatment (29). However, the present study concluded that 17-AAG is able to arrest HCT-116 cells at the $\mathrm{G}_{2}$ phase, possibly due to a reduction in the levels of cyclin B1 expression.

Under stress, cells initiate programmed cell death, termed apoptosis, which is important for various physical and pathological processes and is an important regulator of cell growth (30). The hallmarks of apoptosis are changes in cell morphology, including chromatin condensation, nuclear fragmentation and cell shrinkage, as well as biochemical changes, including caspase activation, degradation of DNA and proteins and the rupture of membrane modification factors, which target cells for phagocytosis (31). There are two major apoptosis signaling pathways: The intrinsic mitochondrial apoptosis pathway and the extrinsic death receptor-mediated apoptosis pathway (32). Intracellular toxicity stimuli, including DNA damage and growth factor deficiency, trigger an increase in mitochondrial membrane permeability and the release of intermembrane proteins, particularly cyt- $c$, initiating intrinsic apoptosis (33). Following its release, and aided by ATP or deoxyadenosine triphosphate, cyt- $c$ is able to form apoptotic bodies with caspase regulatory factors, and activate caspase 9 , and downstream caspase 3 and caspase 7 proteins, to initiate the process of cell apoptosis (34). Abnormal levels of apoptosis disrupt the balance between viable and dead cells to promote tumor development (35); therefore, the regulation of alterations in apoptosis may be a novel anticancer therapy. This present study identified the apoptosis-inducing ability of 17-AAG, but the underlying mechanisms require further investigation. In the present study, an increase in the mRNA and protein expression levels of cyt- $c$, caspase 9 and caspase 3 in HCT-116 cells was detected to varied extents following 17-AAG treatment. These results demonstrated that 17-AAG may induce the apoptosis of HCT-116 cells via the mitochondrial apoptosis signaling pathway in a concentration-dependent manner.

The present study revealed that the expression of STAT3 in the 17-AAG-treated groups was significantly downregulated, indicating that a reduction in STAT3 expression levels may underlie the inhibitory effect of 17-AAG on HCT-116 cells. Members of the STAT family of proteins function in various physical and pathological processes, including cell growth, proliferation and development (36). In particular, STAT3 is important for transcription regulation, post-translational modification and cell functions, including apoptosis and cell death (37). STAT3 is able to translocate into the cell nucleus and bind with specific promoter sequences to regulate transcription. Therefore, STAT3 is able to exert a role in cell proliferation, differentiation and metabolism, processes that are important 

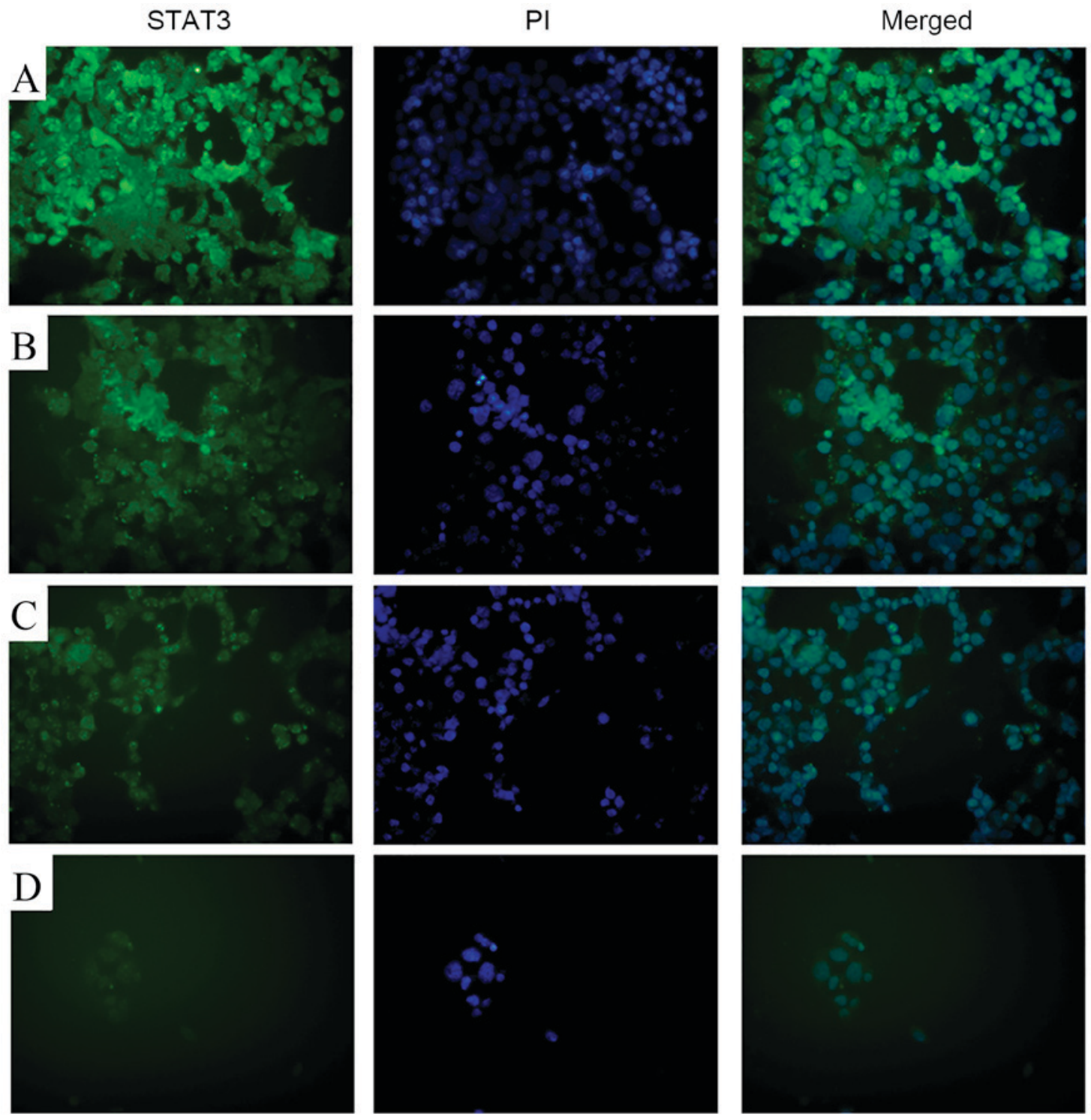

Figure 6. Effect of 17-AAG treatment on STAT3 expression levels in HCT-116 cells as detected by immunofluorescence. (A) Control group; (B) $1.25 \mathrm{mg} / \mathrm{l}$; (C) $2.5 \mathrm{mg} / 1$; (D) $5 \mathrm{mg} / 1$. Following 17-AAG treatment for $48 \mathrm{~h}$, STAT3 expression was markedly decreased. 17-AAG, 17-allylamino-17-demethoxygeldanamycin; STAT3, signal transducer and activator of transcription; PI, propidium iodide.

during the development of inflammation and tumor formation and progression (38). Previous studies have detected STAT3 overexpression in numerous forms of carcinoma, including colorectal cancer, and the loss of control of STAT3 expression in breast, head and neck, prostate, pancreatic, ovarian and brain cancer $(39,40)$. STAT3 is hypothesized to be an important tumor modulatory factor (32), and is able to induce cell proliferation, differentiation and antiapoptotic mechanisms following activation by carcinogenic substances, including B7H3 (41). Leptin is able to elevate hsp90 expression levels via STAT3 regulation, to promote the elevation of human epidermal growth factor receptor 2 expression levels; however, 17-AAG is able to abrogate this effect and inhibit breast cancer cell proliferation (42). This result implicates STAT3 in the anticancer functions of 17-AAG, particularly the inhibition of cell proliferation.

Cyclin D1 is an established downstream target of STAT3, and cyclin D1 expression is decreased upon STAT3 suppression (43). The present study revealed that STAT3 expression in HCT-116 cells was decreased in the 17-AAG-treated groups using RT-qPCR, western blotting and immunofluorescence data. In addition, the current study detected significantly reduced cyclin D1 mRNA and protein expression levels in 17-AAG-treated cells. Therefore, it was hypothesized that 17-AAG may downregulate the expression of cyclin D1 and cyclin B1 via STAT3, in order to induce $\mathrm{G}_{2}$ phase arrest in HCT-116 cells.

Previous studies have suggested that, upon STAT3 inhibition, the expression levels of caspase 3 may be increased $(44,45)$. In addition, Duan et al (46) revealed that thymic stromal lymphopoietin may downregulate caspase 3 expression through the activation of the STAT3 signaling pathway, thereby suppressing the apoptosis of decidual $\gamma \delta \mathrm{T}$ cells (17), indicating that caspase 3 may be a target of STAT3. Previous studies reported that some novel medicines, including geraniin are able to induce the intrinsic apoptosis signaling pathway via the STAT3 pathway (47-49), catalyzing the caspase cascade response. Therefore, it has been suggested that STAT3 may translocate into mitochondria and regulate apoptosis (50). 
In conclusion, the present study revealed the downregulation of STAT3 expression following 17-AAG-treatment in HCT-116 cells, hypothesizing that 17-AAG may regulate mitochondrial apoptosis via the STAT3 signaling pathway, leading to apoptosis induction. However, further studies are required to elucidate the role of STAT3 in the 17-AAG-induced apoptosis of HCT-116 cells.

\section{Acknowledgements}

The present study was supported by the Hebei Province Education Department (grant no. ZD20140003) and University Emphasis Subject of Hebei Province and Immunology Emphasis Subject of Chengde Medical University

\section{References}

1. Haddock MG: Intraoperative radiation therapy for colon and rectal cancers: A clinical review. Radiat Oncol 12: 11, 2017.

2. Seeber A and Gastl G: Targeted therapy of colorectal cancer. Oncol Res Treat 39: 796-802, 2016.

3. Chen G, Yang Z, Eshleman JR, Netto GJ and Lin MT: Molecular diagnostics for precision medicine in colorectal cancer: Current status and future perspective. Biomed Res Int 2016: 9850690 , 2016.

4. Wang C, Zhang Y, Guo K, Wang N, Jin H, Liu Y and Qin W: Heat shock proteins in hepatocellular carcinoma: Molecular mechanism and therapeutic potential. Int J Cancer 138: 1824-1834, 2016.

5. Dimopoulos MA, Mitsiades CS, Anderson KC and Richardson PG: Tanespimycin as antitumor therapy. Clin Lymphoma Myeloma Leuk 11: 17-22, 2011.

6. Solárová Z, Mojžiš J and Solár P: Hsp90 inhibitor as a sensitizer of cancer cells to different therapies (Review). Int J Oncol 46: 907-926, 2015

7. Hong DS, Banerji U, Tavana B, George GC, Aaron J and Kurzrock R: Targeting the molecular chaperone heat shock protein 90 (HSP90): Lessons learned and future directions. Cancer Treat Rev 39: 375-387, 2013.

8. Soroka J, Wandinger SK, Mäusbacher N, Schreiber T, Richter K, Daub $\mathrm{H}$ and Buchner J: Conformational switching of the molecular chaperone Hsp90 via regulated phosphorylation. Mol Cell 45: 517-528, 2012.

9. Tian YZ, Usman T, Tian KC, Di J, Huang XX, Xu XM, Tulafu H, $\mathrm{Wu} \mathrm{WW}, \mathrm{Fu} \mathrm{XF}$, Bai Y, et al: Comparative study of 13 candidate genes applying multi-reference normalization to detect the expression of different fineness in skin tissues of wool sheep. Genet Mol Res 16: 2017.

10. Kathiria AS, Neumann WL, Rhees J, Hotchkiss E, Cheng Y, Genta RM, Meltzer SJ, Souza RF and Theiss AL: Prohibitin attenuates colitis-associated tumorigenesis in mice by modulating p53 and STAT3 apoptotic responses. Cancer Res 72: 5778-5789, 2012.

11. Pimienta G, Herbert KM and Regan L: A compound that inhibits the HOP-Hsp90 complex formation and has unique killing effects in breast cancer cell lines. Mol Pharm 8: 2252-2261, 2011.

12. Sharp SY, Roe SM, Kazlauskas E, Cikotienè I, Workman P, Matulis D and Prodromou C: Cocrystalization and in vitro biological characterization of 5-aryl-4-(5-substituted-2-4-dihy droxyphenyl)-1,2,3-thiadiazole hsp90 inhibitors. PLoS One 7: e44642, 2012.

13. Giubellino A, Sourbier C, Lee MJ, Scroggins B, Bullova P, Landau M, Ying W, Neckers L, Trepel JB and Pacak K: Targeting heat shock protein 90 for the treatment of malignant pheochromocytoma. PLoS One 8: e56083, 2013.

14. Barrott JJ and Haystead TA: Hsp90, an unlikely ally in the war on cancer. FEBS J 280: 1381-1396, 2013.

15. Ye XY, Luo QQ, Xu YH, Tang NW, Niu XM, Li ZM, Shen SP, Lu S and Chen ZW: 17-AAG suppresses growth and invasion of lung adenocarcinoma cells via regulation of the LATS1/YAP pathway. J Cell Mol Med 19: 651-663, 2015.

16. Guo W, Siegel D and Ross D: Stability of the Hsp90 inhibitor 17AAG hydroquinone and prevention of metal-catalyzed oxidation. J Pharm Sci 97: 5147-5157, 2008.
17. Mita AC, Mita MM, Nawrocki ST and Giles FJ: Survivin: Key regulator of mitosis and apoptosis and novel target for cancer therapeutics. Clin Cancer Res 14: 5000-5005, 2008.

18. Ambrosini G, Adida C and Altieri DC: A novel anti-apoptosis gene, survivin, expressed in cancer and lymphoma. Nat Med 3: 917-921, 1997.

19. Yao JQ, Liu QH, Chen X, Yang Q, Xu ZY, Hu F, Wang L and Li JM: Hsp90 inhibitor 17-allylamino-17-demethoxygeldanamycin inhibits the proliferation of ARPE-19 cells. J Biomed Sci 17: 30, 2010.

20. Napper JM and Sollars VE: 17-N-Allylamino-17-demethoxygeldanamycin induces a diverse response in human acute myelogenous cells. Leuk Res 34: 1493-1500, 2010.

21. Chen M, Xu J and Zhao J: Effects of HSP90 inhibitor 17-AAG on cell cycle and apoptosis of human gastric cancer cell lines SGC-7901. Nan Fang Yi Ke Da Xue Xue Bao 33: 271-275, 2013 (In Chinese).

22. Watanabe G, Behrns KE, Kim JS and Kim RD: Heat shock protein 90 inhibition abrogates heaptocellular cancer growth through cdc2-mediated $\mathrm{G} 2 / \mathrm{M}$ cell cycle arrest and apoptosis. Cancer Chemother PHarmacol 64: 433-443, 2009.

23. Karkoulis PK, Stravopodis DJ, Margaritis LH and Voutsinas GE: 17-Allylamino-17-demethoxygeldanamycin induces downregulation of critical Hsp90 protein clients and results in cell cycle arrest and apoptosis of human urinary bladder cancer cells. BMC Cancer 10: 481, 2010.

24. Mikhail S, Albanese C and Pishvaian MJ: Cyclin-dependent kinase inhibitors and the treatment of gastrointestinal cancers. Am J Pathol 185: 1185-1197, 2015.

25. Swaffer MP, Jones AW, Flynn HR, Snijders AP and Nurse P: CDK substrate phosphorylation and ordering the cell cycle. Cell 167: 1750-1761.e16, 2016.

26. Bilal I, Chowdhury A, Davidson J and Whitehead S: Phytoestrogens and prevention of breast cancer: The contentious debate. World J Clin Oncol 5: 705-712, 2014.

27. Poli A, Ramazzotti G, Matteucci A, Manzoli L, Lonetti A, Suh PG, McCubrey JA and Cocco L: A novel DAG-dependent mechanism links PKCa and Cyclin B1 regulating cell cycle progression. Oncotarget 5: 11526-11540, 2014.

28. Gong D and Ferrell JE Jr: The roles of Cyclin A2, B1, and B2 in early and late mitotic events. Mol Biol Cell 21: 3149-3161, 2010.

29. Powers MV, Valenti M, Miranda S, Maloney A, Eccles SA, Thomas G, Clarke PA and Workman P: Mode of cell death induced by the HSP90 inhibitor 17-AAG (tanespimycin) is dependent on the expression of pro-apoptotic BAX. Oncotarget 4: 1963-1975, 2013.

30. Matos AJ and Santos AA: Advances in the understanding of the clinically relevant genetic pathways and molecular aspects of canine mammary tumours: Part 1 . Proliferation, apoptosis and DNA repair. Vet J 205: 136-143, 2015.

31. Guicciardi ME, Malhi H, Mott JL and Gores GJ: Apoptosis and necrosis in the liver. Compr Physiol 3: 977-1010, 2013.

32. McCracken JM and Allen LA: Regulation of human neutrophil apoptosis and lifespan in health and disease. J Cell Death 7: 15-23, 2014.

33. Apostolova N and Victor VM: Molecular Strategies for targeting antioxidants to mitochondria: Therapeutic implications. Antioxid Redox Signal 22: 686-729, 2015.

34. Hilgendorf KI, Leshchiner ES, Nedelcu S, Maynard MA, Calo E, Ianari A, Walensky LD and Lees JA: The retinoblastoma protein induces apoptosis directly at the mitochondria. Genes Dev 27: 1003-1015, 2013.

35. Hassan M, Watari H, AbuAlmaaty A, Ohba Y and Sakuragi N: Apoptosis and molecular targeting therapy in cancer. Biomed Res Int 2014: 150845, 2014.

36. Hong S, Mehta KP and Laimins LA: Suppression of STAT-1 expression by human papillomaviruses is necessary for differentiation-dependent genome amplification and plasmid Maintenance. J Virol 85: 9486-1994, 2011.

37. Kamran MZ, Patil P and Gude RP: Role of STAT3 in cancer metastasis and translational advances. Biomed Res Int 2013: 421821, 2013.

38. Yuan J, Zhang F and Niu R: Multiple regulation pathways and pivotal biological functions of STAT3 in cancer. Sci Rep 5: $17663,2015$.

39. Giordano C, Vizza D, Panza S, Barone I, Bonofiglio D, Lanzino M, Sisci D, De Amicis F, Fuqua SA, Catalano S and Andò S: Leptin increases HER2 protein levels through a STAT3-mediated up-regulation of Hsp90 in breast cancer cells. Mol Oncol 7: 379-391, 2013. 
40. Huang W, Dong Z, Wang F, Peng H, Liu JY and Zhang JT: A small molecule compound targeting STAT3 DNA-binding domain inhibits cancer cell proliferation, migration, and invasion. ACS Chem Biol 9: 1188-1196, 2014.

41. Li Y, Guo G, Song J, Cai Z, Yang J, Chen Z, Wang Y, Huang Y and Gao Q: B7-H3 promotes the migration and invasion of human bladder cancer cells via the PI3K/Akt/STAT3 signaling Pathway. J Cancer 8: 816-824, 2017.

42. Chaudhari N, Talwar P, Parimisetty A, Lefebvre d'Hellencourt C and Ravanan P: A molecular web: Endoplasmic reticulum stress, inflammation, and oxidative stress. Front Cell Neurosci 8: 213, 2014.

43. Qin A, Yu Q, Gao Y, Tan J, Huang H, Qiao Z and Qian W: Inhibition of STAT3/cyclinD1 pathway promotes chemotherapeutic sensitivity of colorectal caner. Biochem BiopHys Res Commun 457: 681-687, 2015.

44. Kamran MZ, Patil P and Gude RP: Role of STAT3 in cancer metastasis and translational advances. Biomed Res Int 2013 421821, 2013

45. Cimica V, Chen HC, Iyer JK and Reich NC: Dynamics of the STAT3 transcription factor: Nuclear import dependent on ran and importin- $\beta 1$. PLoS One 6: e20188, 2011.

46. Duan J, Jiang XP, Li MQ, Fan DX, Wang Y, Li DJ and Jin LP: Thymic stromal lympHopoietin suppresses the apoptosis of decidual gamma-delta $\mathrm{T}$ cells via regulation of the signal transduction and activation of transcription 3/caspase-3 signaling pathway. Am J Reprod Immunol 70: 464-471, 2013.
47. Zhu Y,Doornebal EJ, Pirtskhalava T, Giorgadze N, Wentworth M, Fuhrmann-Stroissnigg H, Niedernhofer LJ, Robbins PD, Tchkonia T and Kirkland JL: New agents that target senescent cells: The flavone, fisetin, and the BCL-XL inhibitors, A1331852 and A1155463. Aging (Albany NY) 9: 955-963, 2017.

48. Do DV, Ueda J, Messerschmidt DM, Lorthongpanich C, Zhou Y, Feng B, Guo G, Lin PJ, Hossain MZ, Zhang W, et al: A genetic and developmental pathway from STAT3 to the OCT4-NANOG circuit is essential for maintenance of ICM lineages in vivo. Genes Dev 27: 1378-1390, 2013.

49. Ren Z, Zou W, Cui J, Liu L, Qing Y and Li Y: Geraniin suppresses tumor cell growth and triggers apoptosis in human glioma via inhibition of STAT3 signaling. Cytotechnology 2017 (Epub ahead of print).

50. Carbognin E, Betto RM, Soriano ME, Smith AG and Martello G: Stat 3 promotes mitochondrial transcription and oxidative respiration during maintenance and induction of naive pluripotency. EMBO J 35: 618-634, 2016 